\title{
Tenure Impacts on Livelihood, Income, Forest Condition, and Equity of an Upland Community in Negros Occidental, Philippines
}

\author{
Nicole Nacionales ${ }^{{ }^{*}}$ and Dixon Gevaña ${ }^{2}$ \\ 1 Graduate Student, University of the Philippines Los Baños, Laguna, Philippines; nanacionales@up.edu.ph \\ 2 Associate Professor, Department of Social Forestry and Forest Governance, College of Forestry and \\ Natural Resources, University of the Philippines Los Baños, Laguna, Philippines; dtgevana@up.edu.ph \\ * Correspondence author: Tel.: +63-916-629-4173
}

\begin{abstract}
This study examined the perceived impacts of the Integrated Social Forestry Program (ISFP) on the biophysical and socio-economic conditions of farmers in Barangay Patag, Silay City, Negros Occidental, Philippines. Specifically, it aimed to: (a) assess the perceived impacts of ISFP on local livelihood, income, forest condition, and equity (LIFE); and (b) identify the factors that are associated with perceived equity; and (c) determine the relationships between perceived equity and ISFP goals. Data were gathered through surveys and a focused group discussion. A total of 41 respondents composed the survey, while six key informants comprised the focused discussion group. Key findings showed that ISFP was perceived to have considerable beneficial impacts on livelihood and income sources. It also had positive impacts on forest condition particularly in the perceived increased of forest cover. Some beneficial impacts were likewise noted for equity across dimensions: gender; education; economic status; and membership. Finally, challenges in sustaining the program underscored the need for strategies to further enhance its positive impacts on the local community's socio-ecological conditions.
\end{abstract}

Keywords: Community; Social forestry; Tenure; Impacts; LIFE indicator.

\section{Introduction}

History explains how the Philippines forest was influenced by the changes in culture, policy, and governance. In the early 15th century, the country's forests were described to be pristine (Maohong, 2012) in which around 27 million hectares (ha) of tropical rainforests, managed by many indigenous people, covered the whole Philippine archipelago. Logging and shifting cultivation, resulting to significant deforestation, have started to expand during the Spanish colonial period and these events later prompted the creation of Inspeccion General de Montes (IGM) ${ }^{1}$ in 1863 (FMBDENR, 2021). By 1900 under the American regime, forest cover further decreased to 21 million ha as logging persisted (Pulhin, 2002) and by the end of 1941, the country's forest had declined significantly to only 17 million ha. During the Japanese occupation and World War II, which started in 1942, deforestation challenges remained as logging continued.

The Philippines regained its independence in 1946. Three decades later, the Presidential Decree No. 705 (The Revised Forestry Code of 1975) was passed to allocate all forest lands under the ownership of the state. Social forestry programs were developed in regulating illegal logging and cultivation in the uplands. As a consolidation of forestry programs: Forest Occupancy Management (FOM) of 1975; Family Approach to Reforestation (FAR) of 1976; and Communal Tree Farming (CTF) of 1978, the Integrated Social Forestry Program (ISFP) was put into policy through a Letter of Instruction 1260 in 1982.

\footnotetext{
${ }^{1}$ Inspeccion General de Montes is an agency holding the sole management and authority over the forest lands.
} 
The establishment of ISFP provided an opportunity for upland communities to address the challenges of deforestation and upland development. It was supported by the local government units (LGUs) by virtue of the national law on forest devolution known as Republic Act 7160 or Local Government Code of 1991. It regulates in parallel with a similar land tenure program entitled Community-Based Forest Management (CBFM). Both ISFP and CBFM are designed to improve local livelihoods, income, forest condition, and equity (collectively termed as LIFE) (Pulhin et. al, 2008).

Like many rural development programs, ISFP confronts difficult challenges. According to Ramirez (1991), the program has some limitations in enforcing forest protection and encouraging local participation in forest rehabilitation and protection initiatives. These transpired from: (1) unclear access and utilization rights of local communities over forest lands that were devolved to them (Masipiquena, 1993); (2) limited technical and financial capacity of local government units to implement the program (Enrique, 1992; Orias and Bande, 2018); and (3) overlapping land use development projects over the same ISFP sites. Further, many of the program beneficiaries remained dependent on government assistance in improving their way of living (Ramirez, 1991). Masipiquena (1993) also noted that their socio-economic condition did not improve much because of unpredictable and seasonal livelihood and income that the local government provides (Ramirez, 1991).

To empower forest communities, the capacity of people's organizations to fully function became a criterion for it to organize independently from the government (Dizon, 2004; Gevaña 2009; Pulhin et al., 2017; Ruzol et al. 2020, Peras et al, 2021). Hence, this study examined how LIFE was perceived through the adoption of ISFP. Specifically, it (a) assessed the perceived impact of ISFP on local livelihood, income, forest condition, and equity; (b) identified factors associated with equity; (c) evaluated the relationships of equity and ISFP goals; and (d) described the issues and challenges in ISFP.

\section{Materials and Methods}

\subsection{The Study Site}

Barangay ${ }^{2}$ Patag, Silay City, Negros Occidental is one of the pioneer sites covered by ISFP in Negros Island. The site was selected because of its accessibility, size (area), good representation of an organized upland community, and adoption of various agroforestry technologies.

Barangay Patag has a total land area of 3,951.91hectares and it is located at $10^{\circ}$ North and $123^{\circ}$ East (Figure 1). It is bounded at the North by Malogo River, at the West by Barangay Kapitan Ramon and Barangay Guimbala-on, at the East by Northern Negros Natural Park, and at the South by Talisay City. The soil in Barangay Patag is comprised of rough mountainous land and this type of soil is suited to Type III climate ${ }^{3}$.

According to the City Planning and Development Office - City Government of Silay (2016), this village was established on May 15, 1985, through a referendum by the government of Silay City. Historians and local people are familiar with the documented ancient stories during World War II. Barangay Patag is notable for its astounding natural resources, drawing attention to the unique biodiversity of the locality and is also acknowledged for its overflowing rivers and waterfalls (CENRO, Cadiz City, 2016; DENR, 2016).

The government interventions changed the path of the forest industry in Barangay Patag at the beginning of the 1980s. These involved the forest occupants in decision-making processes on how to reforest and manage the remaining forested areas that were saved from deforestation. When the majority of the forest occupants supported these interventions, ISFP in Barangay Patag in 1982 was adopted. Forest occupants were then provided land tenure through Certificates of Stewardship (CSCs).

On the onset of ISFP, there were 136 individual CSC holders in Patag. They were organized into a People's Organization (PO) known as Patag Farmers Integrated Social Forestry Association

\footnotetext{
${ }^{2} \mathrm{~A}$ barangay or village is the smallest political unit in the Philippines.

${ }^{3}$ Type III climate is when the seasons are not very pronounced but it is relatively dry from November to April and wet during the rest of the year.
} 
(PAFISFA). Over the years, membership has declined to only about 68 active members (2016). Some members migrated to other provinces while others looked for livelihoods other than farming. Few members were noted to have remained active and had the CSCS transferred to their next of kin. The ISFP tenure policy provides that CSC cannot be transferred to non-ISFP participants, but may be transferred only to the holder's next of kin.

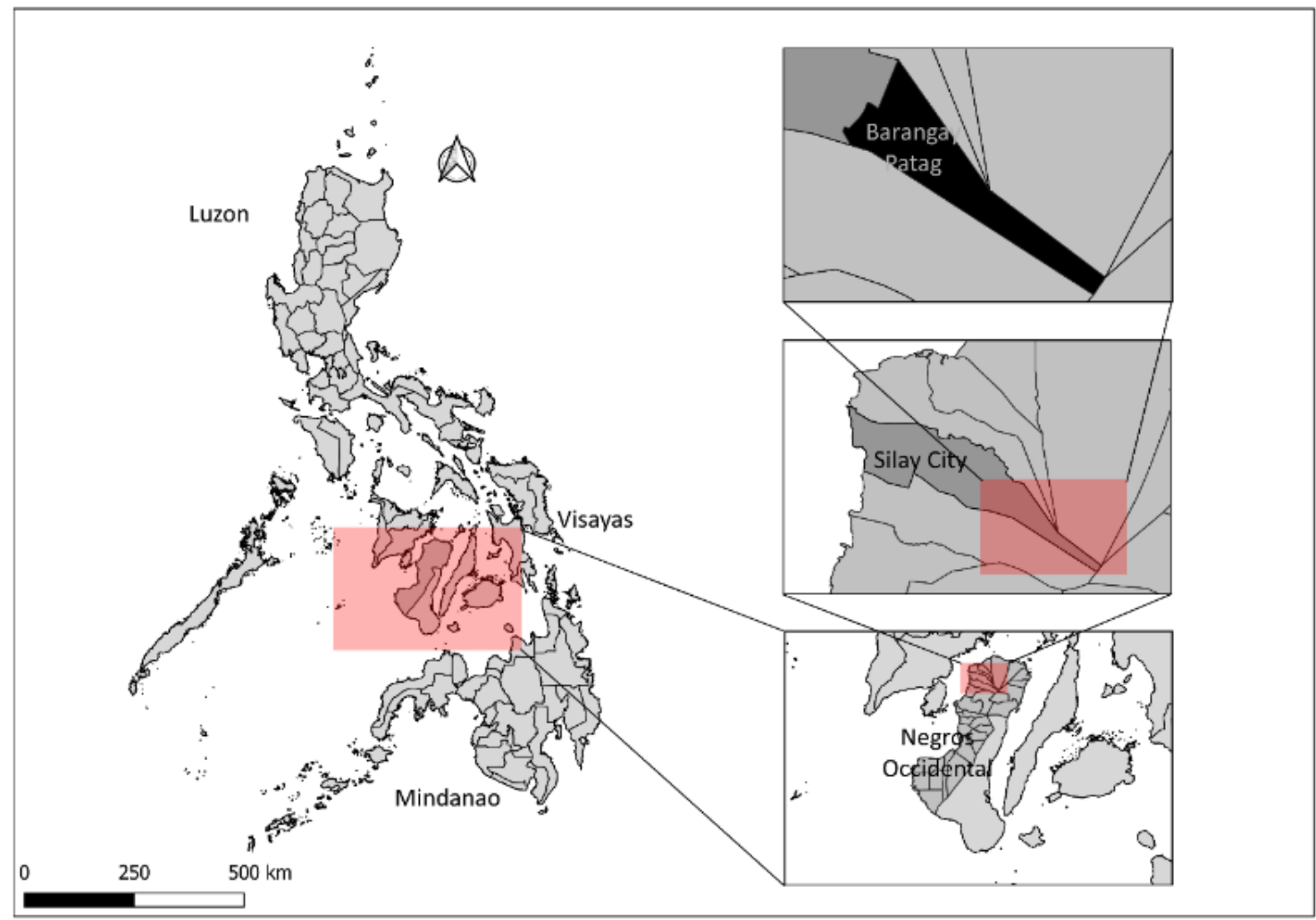

Figure 1. Location Map of Barangay Patag, Silay City, Negros Occidental

\subsection{Data Collection and Focus Group Discussion}

A survey was carried out with 41 members. This survey largely included questions on the socioeconomic and demographic conditions, and also perceptions on the changes/impacts made by ISFP to LIFE. Snowball sampling was applied on survey interviews and these interviews were carried out in Tagalog and llonggo dialects. The minimum number of respondents was determined using Slovin's equation with a margin of error of $10 \%$ (Yamane, 1967):

$$
n=\frac{N}{\left(1+N e^{2}\right)}
$$

Where $\mathrm{n}$ is the sample size, $\mathrm{N}$ is the population size, and e is the margin of error.

$$
n=\frac{68}{\left[1+68(0.10)^{2}\right]}=41
$$

Survey results were validated through focused group discussion (FGD). General questions to validate and enrich the survey findings were used. These included: "What would the group say about the positive impact of ISFP on livelihood as a result of its issuance?" and "How do you consider your income in terms of meeting the needs of your family?".

Secondary data (e.g., reports, maps, records of PO meetings, local development plans, etc.) were gathered from the PAFISFA, Provincial Environmental and Natural Resources Office (PENRO) of Negros Occidental, Office of the Mayor of Silay City, Department of Tourism (DOT), and Barangay Patag Office. The satellite image of the study area was also obtained through Hansen (2013) /UMD/Google/USGS/NASA (http://earthenginepartners.appspot.com/science-2013-global-forest). 


\subsection{Data Collating and Statistical Analysis}

A coding guide was formulated to generate data from the survey interviews. LIFE served as the indicator for understanding the perceptions of the respondents. A Likert scale was used to gauge and interpret perceptions (Yamane, 1999). Descriptive statistics, such as frequencies, percentages, and means, were generated. Further, Point-biserial correlation and Spearman's rank-order correlation coefficient tests were performed using IBM SPSS Statistics 19 to test the relationship between the respondent's socio-economic conditions and their perceptions on equity and ISFP goals.

\section{Results and Discussion}

\subsection{Socio-economic and demographic characteristics}

\subsubsection{Demography}

Figure 2 presents the socio-demographic characteristics of the respondents, in terms of age, sex, educational attainment, religion, and migration. Most of the respondents were between ages 45 to 51 years old, and the majority were married. The highest level of education completed was mostly represented by those who did not accomplish elementary level education. The greatest number of respondents were native to the area and few of them were migrants, who came from the nearby towns and provinces in pursuit of livelihoods. The representation of male and female was almost equal.

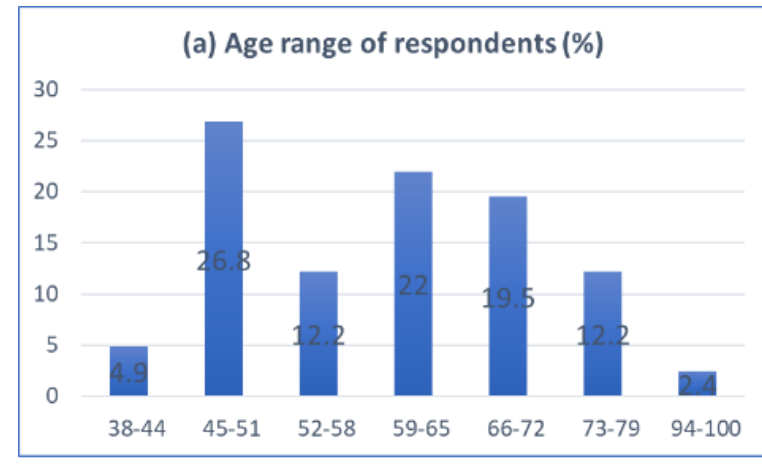

(c) Educational Attainment of respondents (\%)

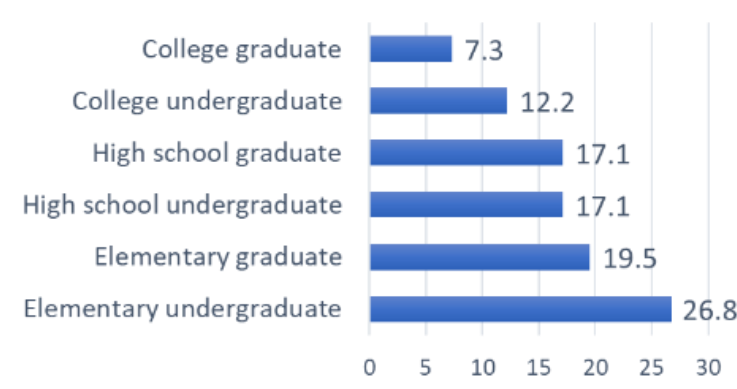

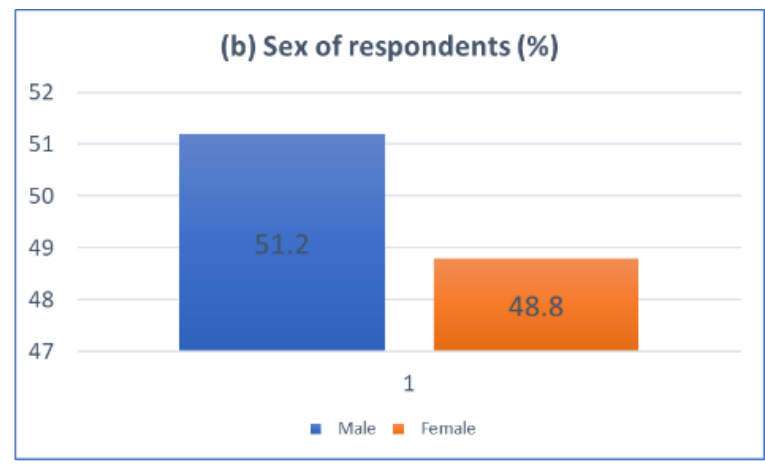

(d) Migration status of respondents (\%)

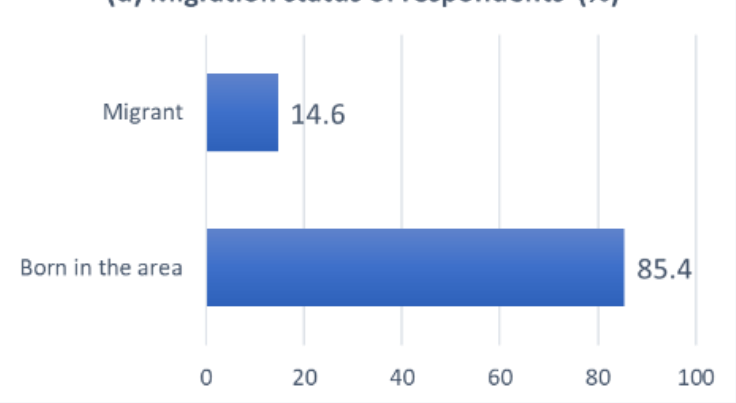

Figure 2. Basic socio-demographic characteristics of the respondents

\subsubsection{Livelihood}

According to the Annual Survey of the Philippine Business and Industry (2013), growing of crops had the largest engagement in agriculture, forestry, and fishing industry. This was also reflected in respondent livelihoods as they worked mainly as farmers (53.7\%) (Figure 3). They practiced agroforestry, particularly organic farming along sloping areas. Some farmers engaged in planting high-value crops, such as broccoli, cabbage, and the like, and growing fruit trees and root vegetables, such as avocado, banana, sweet potato, and taro. 


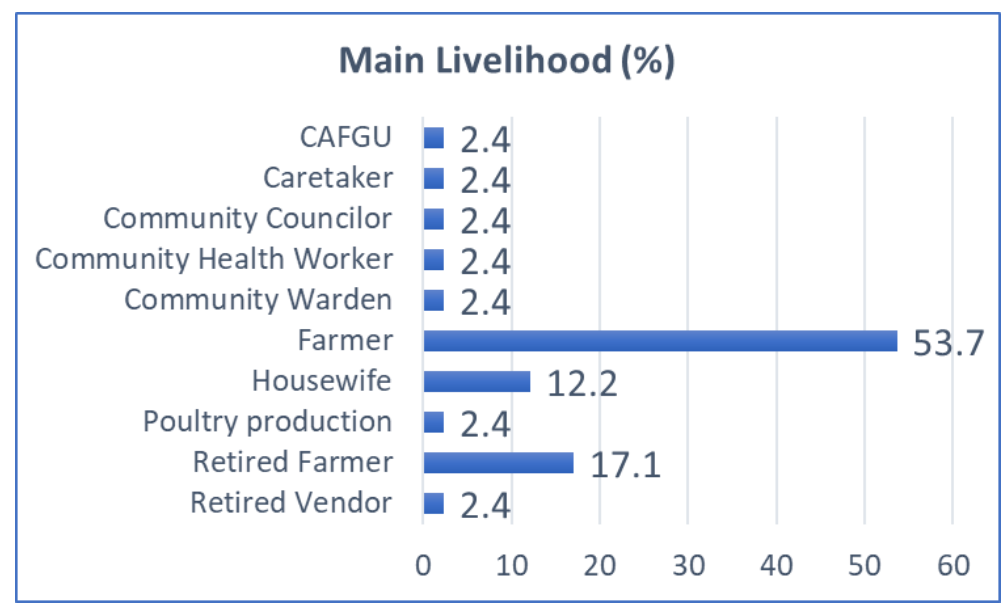

Figure 3. Main livelihood of the respondents

\subsubsection{Income}

Figure 4 summarizes the respondents' (a) dependency on forest-based source of income and (b) individual income from forest-based sources. The annual income accumulated from these forestbased livelihoods had an average of $\$ 34,150.8 /$ year (716 USD/year) and about $68.3 \%$ of the respondents received below $\$ 30,000 /$ year (below 629 USD/year).

Individual income was solely based on forest-based annual income since there was a lack of data on non-forest-based income. These income sources were considered on the side and if available, these income sources were seasonal and owned by other family members. Despite the low income, the farmers noted that their individual contribution to the overall household income were as important as the income contribution of other family members. Also, the resources that they were producing were beneficial to offset expenses on food.
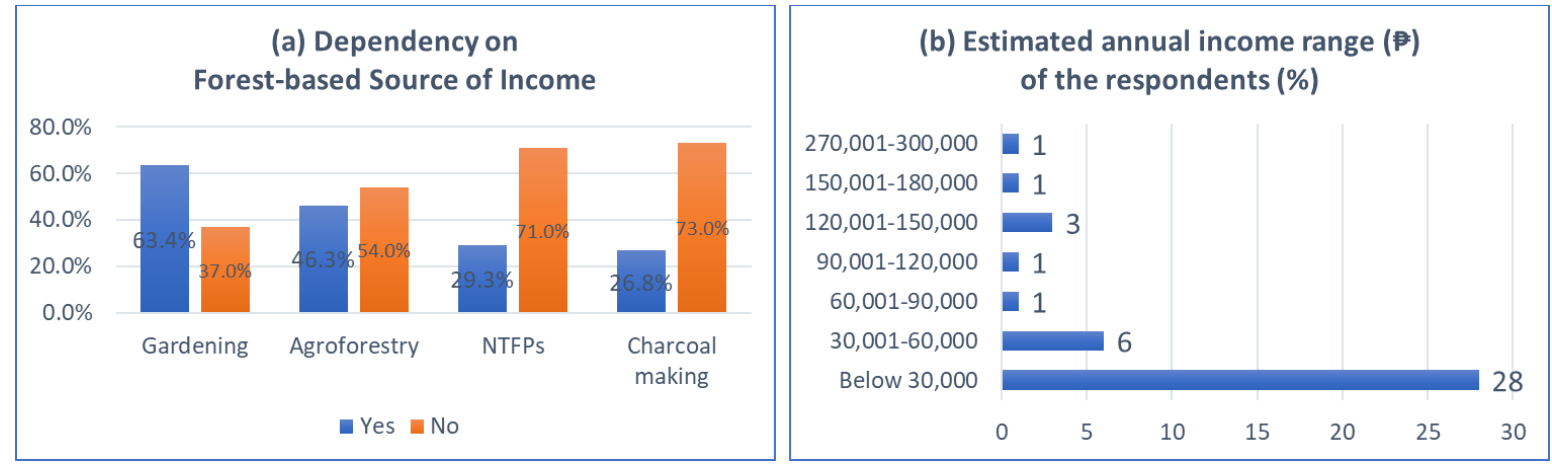

Figure 4. Dependency on Forest-based Source of Income and Estimated individual annual forestbased income range

\subsection{Impacts of ISFP to Livelihood, Income, Forest Condition, and Equity}

\subsubsection{On Livelihood}

Communities depend on natural resources, especially those who are situated on upland forests and forest lands, which compensates for the absence of employment and livelihood opportunities (Adams et al., 2004; Chokkalingam et al., 2006; Chechina et al., 2018). In Brgy. Patag, livelihoods before ISFP were generally described by FGD participants to be destructive to the environment. Many forest occupants were engaged in illegal logging and uncontrolled shifting cultivation/kainginmaking. Through time, the negative impacts of these activities have manifested and hence some began to shift to agroforestry. ISFP was then implemented when the collective actions of the forest occupants were recognized by the government.

Farming was observed to be the major livelihood in the community (Figure 3). Livelihoods increased through ISFP. More opportunities became available through time and ISFP was a big contributor to the increasing livelihood. As much as $80.5 \%$ of the respondents expressed that they were able to secure a livelihood through ISFP (Figure 5). A few of them were also engaged in non- 
forest related livelihoods such as trading, buying and selling, and blue-collar (manual laborers) and white-collar jobs (office-based jobs). Further, respondents became more knowledgeable as they participated in different training and seminars that focused on agroforestry, livestock and poultry production, and organic farming (Macahilo, 2018).

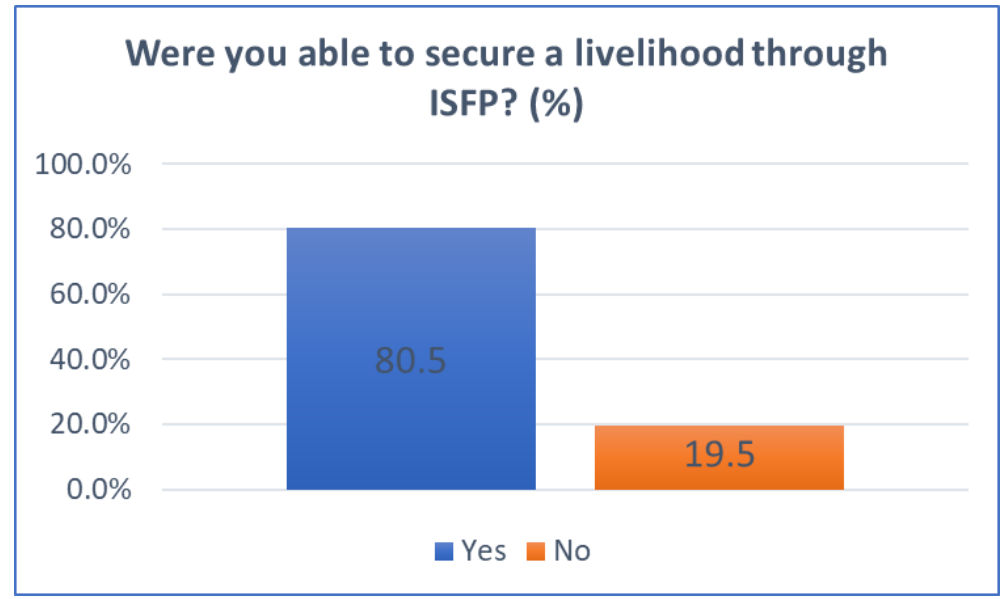

Figure 5. Livelihood as a benefit from ISFP

\subsubsection{Impact of ISFP on Ownership of Assets}

As the community has the right to own the forest, the ownership of assets varies between community members (Antinori \& Rausser, 2007). Provision of assets such as land, house, livestock, farm tools and equipment (carabao hand tractors), transportation, household appliances, and technology was also attributed to the adoption of ISF program (Table 1).

As perceived by the respondents, land size had significantly increased after ISFP was implemented. They indicated that ISFP made it possible to formally and legally acquire land rights through CSC. This provided them tenure security in building their home and farms, and opportunities to grow different crops on their own land.

House quality was also perceived to have slightly increased. The implementation of ISFP had granted tenured migrants the opportunity to permanently build houses by utilizing wood materials from the trees they planted.

Livestock assets had slightly increased. ISFP enhanced the regulation of income through livestock production. Livestock assets helped the respondents to gain additional income by selling raw material and final products.

Farm tools and equipment assets, such as carabao and hand tractors, and household appliances had slightly increased as well. The resources in attaining these assets were generally perceived to have resulted from the benefits of projects and livelihood opportunities provided through ISFP.

Transportation assets did not change. The government provided CSC holders with various livelihoods training. Technological assets, in terms of skills on agroforestry, composting, Integrated Pest Management (IPM), organic farming, and Sloping Agricultural Land Technology (SALT), had significantly increased. Secure land tenure promotes an investment for improved homes and livelihoods (UN Habitat, 2020).

Table 1. Summary of perception on the impact of ISFP on ownership of assets

\begin{tabular}{lcc}
\hline Ownership of Assets & Mean Scores & Perception \\
\hline Change in land size & 4.44 & Significantly increased \\
\hline Change in house quality & 3.90 & Slightly increased \\
\hline Change in livestock assets & 3.71 & Slightly increased \\
\hline $\begin{array}{l}\text { Change in farm tools and } \\
\text { equipment }\end{array}$ & 3.51 & Slightly increased \\
\hline $\begin{array}{l}\text { Change in household } \\
\text { appliances }\end{array}$ & 3.66 & Slightly increased \\
\hline
\end{tabular}




\begin{tabular}{lcc}
\hline Ownership of Assets & Mean Scores & Perception \\
\hline Change in land size & 4.44 & Significantly increased \\
\hline $\begin{array}{l}\text { Change in transportation } \\
\text { assets }\end{array}$ & 3.07 & No change \\
\hline Change in technological assets & 4.29 & Significantly increased \\
\hline \multicolumn{2}{l}{ Scale Interpretation } & \\
1.00-1.80 significantly decreased/significantly worsen & \\
1.81-2.60 slightly decreased/slightly worsen & \\
2.61-3.40 no change & \\
3.41-4.20 slightly increased/slightly improved & \\
4.21-5.00 significantly increased/significantly improved &
\end{tabular}

\subsubsection{On Income}

About $41.5 \%$ of the respondents perceived that their forest-based income became sufficient because of ISFP (Table 2). Meanwhile, most (68.3\%) of the respondents perceived a slight increase in their forest-based income compared to previous years (Table 3). Given that forest-based source of income was highly depended on by the respondents, they were still considered poor.

Sometimes members expressed lacking earned income opportunities, because earning through ISFP alone may pose a challenge (Ramirez, 1991). Respondents expressed they were able to meet basic needs through the provisioning services ${ }^{4}$ that the forest produced. Through ISFP, they noted that organic farming also helped them offset some food expenses since they were growing crops for first-hand consumption. There are numerous linkages of achieving ecological and socioeconomic goals in a community and the well-being of the respondents was not defined by forest-based income alone (Levang et al., 2005) since ISFP had widened accessibility to natural resources.

Table 2. Perception on the sufficiency of income

\begin{tabular}{lcc}
\hline Sufficiency of income & Frequency & Percent \\
\hline Very Insufficient & 15 & 36.6 \\
\hline Insufficient & 9 & 22.0 \\
\hline Sufficient & 17 & 41.5 \\
\hline More than sufficient & 0 & 0.0 \\
\hline Excessively abundant & 0 & 0.0 \\
\hline
\end{tabular}

Table 3. Perception on the impacts of ISFP on change of income

\begin{tabular}{lcc}
\hline Change in income & Frequency & Percent \\
\hline Significantly decreased & 0 & 0.0 \\
\hline Slightly decreased & 0 & 0.0 \\
\hline No change & 5 & 12.2 \\
\hline Slightly increased & 28 & 68.3 \\
\hline Significantly increased & 8 & 19.5 \\
\hline
\end{tabular}

\subsubsection{On Forest Condition}

\subsubsection{Improvement of Forest Products}

A community has the right to access and utilize various natural resources (Pulhin et al, 2008). Timber and NTFP resources were perceived to have greatly improved (Table 4 ) and the respondents associated these with continuous tree planting efforts that they had conducted. Fuelwood supply was also noted to have improved because they learned how to grow fast-growing fuelwood species, such as Calliandra spp. and Leucaena leucocephala, on their farms. This also helped reduce dependence on charcoal. Lastly, the majority of respondents perceived that wildlife populations and habitat quality had improved. They associated the improvement with the collective effort of the

\footnotetext{
${ }^{4}$ Provisioning services are material or energy such as food, water, and natural resources derived from an ecosystem.
} 
Bantay Bukid Task Force (Farm Warden Group) in safeguarding the ISFP site from illegal hunting and logging activities.

Table 4. Perception of the improvement of forest products

\begin{tabular}{lccccc}
\hline Products & Decreased & No Change & Increased & Mean & Perception \\
\hline Timber & Percent & Percent & Percent & & \\
\hline NTFPs & 0.0 & 0.0 & 100.0 & 3.00 & Increased \\
\hline Fuelwood & 7.3 & 0.0 & 92.7 & 2.85 & Increased \\
\hline Charcoal & 12.2 & 22.0 & 65.9 & 2.54 & Increased \\
\hline Wildlife & 41.5 & 29.3 & 29.3 & 1.88 & No change \\
\hline Scaln & 0.0 & 7.3 & 92.7 & 2.93 & Increased \\
\hline
\end{tabular}

Scale Interpretation

1.00-1.67 decreased

1.68-2.34 no change

2.35-3.01 increased

\subsubsection{Improvement of Environmental Services}

Numerous environmental services, especially in the forests, are highly recognized and these services are maintained or enhanced (Pasa, 2011). The study shows the decline of destructive farming and resource extractive activities on forested communities. ISFP had improved the environmental services through ecologically-sound practices and policies governed in the community.

Areas affected by deforestation and kaingin were perceived to have decreased because of the implementation of ISFP (Table 5). The respondents emphasized that tree planting efforts of CSC holders had helped improve the ecological quality of farms and forest sites. The areas of remaining natural forest and reforestation were also perceived to have increased because of the vigilant and stricter rules and regulations that were in place.

The area of cultivated lowlands did not change while the upland agricultural areas had increased due to the adoption of agroforestry. The respondents practiced agroforestry technologies they learned, particularly on fruit tree production over these areas. Agroforestry and soil conservation technologies also helped in maintaining soil stability. Thus, it was perceived that there was a decreasing soil erosion problem.

The respondents observed that the area of settlements had increased. This was attributed with the increasing population in their area. As for the water turbidity and water supply, ISFP was viewed to have assisted in maintaining sufficient and clean water for local communities. Lastly, the respondents had recognized the decreasing rate of forest fire due to stricter protection efforts.

Table 5. Perception on the improvement of environmental services

\begin{tabular}{lccccc}
\hline Products & Decreased & $\begin{array}{c}\text { No } \\
\text { Change }\end{array}$ & Increased & Mean & Perception \\
\hline & Percent & Percent & Percent & & \\
\hline Area of deforestation & 90.2 & 7.3 & 2.4 & 1.12 & Decreased \\
\hline Area converted to kaingin & 100.0 & 0.0 & 0.0 & 1.00 & Decreased \\
\hline $\begin{array}{l}\text { Area of remaining natural } \\
\text { forest }\end{array}$ & 2.4 & 2.4 & 95.1 & 2.93 & Increased \\
\hline Area of reforestation & 0.0 & 0.0 & 100.0 & 3.00 & Increased \\
\hline Area of cultivated lowlands & 31.7 & 68.3 & 0.0 & 1.68 & No change \\
\hline Area of agroforestry & 0.0 & 2.4 & 97.6 & 2.98 & Increased \\
\hline Area of settlements & 0.0 & 7.3 & 92.7 & 2.93 & Increased \\
\hline Water turbidity & 0.0 & 73.2 & 26.8 & 2.27 & No change \\
\hline $\begin{array}{l}\text { Water supply for domestic and } \\
\text { irrigation }\end{array}$ & 0.0 & 80.5 & 19.5 & 2.20 & No change \\
\hline Soil Erosion & 75.6 & 17.1 & 7.3 & 1.32 & Decreased \\
\hline Fire & 90.2 & 4.9 & 4.9 & 1.15 & Decreased \\
\hline
\end{tabular}


Scale Interpretation

1.00-1.67 decreased

1.68-2.34 no change

2.35-3.01 increased

\subsubsection{Impact of ISFP on Forest Use and Benefits}

Majority (65.9\%) of the respondents perceived that forest use and benefits on livelihood, water, agricultural land, fuelwood, wildlife, and timber had significantly improved since the implementation of ISFP (Table 6). As mentioned by the FGD participants, the community became more socially and environmentally aware of the need to save their forest. The shift to the increasing plantation of farm and forest species instigated the appreciation on these resources.

Table 6. Perception on the impact of forest use and benefits

\begin{tabular}{lcc}
\hline Impact to forest use and benefits & Frequency & Percent \\
\hline Significantly worsen & 0 & 0.0 \\
\hline Slightly worsen & 0 & 0.0 \\
\hline No change & 1 & 2.4 \\
\hline Slightly improved & 13 & 31.7 \\
\hline Significantly improved & 27 & 65.9 \\
\hline
\end{tabular}

\subsubsection{Forest Condition in the ISFP Area}

A satellite image of the ISFP site indicates improvement in the forest condition of the ISFP area over 12 years. Figure 6 shows the forest gain during the period 2000-2012. As verified by the key informants during the focus group discussion, there was an increase in the forested area since the implementation of ISFP. However, the satellite image cannot fully confirm such perceived observations because of the lack of detailed baseline field data for analyzing the forest gain throughout the 12-year period (CENRO, 2016).

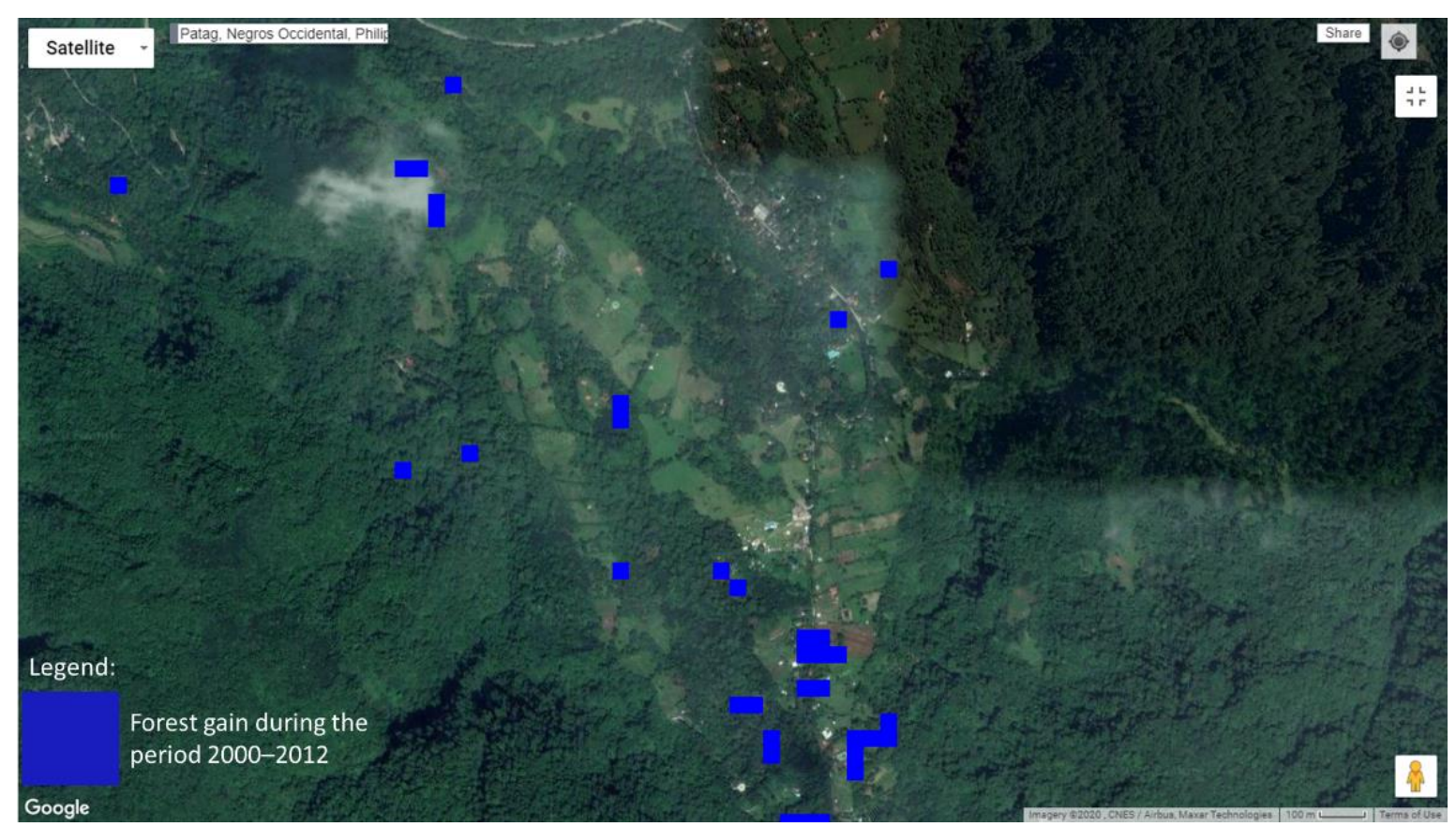

Figure 6. Landsat images characterizing forest extent and change in ISFP site within the period 20002012 (Source: Hansen/UMD/Google/USGS/NASA) 


\subsubsection{On Equity}

3.2.4.1. Perception of Equity across Gender, Educational Attainment, Economic Status, and Membership Status in the People's Organization

Improving equity is achievable through an issuance of tenure (Pulhin et al., 2008). Perceptions of equity across the respondent's gender, educational attainment, economic status, and membership status were evaluated (Richards et al., 2003; Amanor, 2005). Leadership roles and local participation, access to livelihood opportunities, access to people's organization (PO) services, access to major forest-based resources, and sharing of responsibilities were analyzed as impact categories in understanding equity (Table 7 ).

Gender, education, and economic status were perceived to be most equitable when it comes to membership in the executive council/leadership. According to the respondents, they had no conflict in selecting the executive council/leader in terms of gender, educational attainment, and income class.

Lastly, membership was perceived to be most equitable in terms of participation in the PO decision-making process. The respondents were confident that the decisions of organizational members had contributed to the current status of the organization.

Table 7. Summary of the mean-based perception of equity in terms of gender, educational attainment, economic status, and membership status in the Peoples Organization.

\begin{tabular}{|c|c|c|c|c|}
\hline Equity Dimensions & Gender & $\begin{array}{l}\text { Educational } \\
\text { Attainment }\end{array}$ & $\begin{array}{c}\text { Economic } \\
\text { Status }\end{array}$ & Membership \\
\hline \multicolumn{5}{|c|}{ Leadership Roles and Participation } \\
\hline \multirow{2}{*}{$\begin{array}{l}\text { Membership in the executive } \\
\text { council/leadership }\end{array}$} & 4.41 & 4.39 & 4.29 & 3.41 \\
\hline & Strongly agree & Strongly agree & Strongly agree & Agree \\
\hline \multirow{2}{*}{$\begin{array}{l}\text { Participation in PO/community } \\
\text { meetings }\end{array}$} & 4.10 & 4.05 & 3.95 & 3.95 \\
\hline & Agree & Agree & Agree & Agree \\
\hline \multirow{2}{*}{$\begin{array}{l}\text { Participation in the } \mathrm{PO} \\
\text { decision-making processes }\end{array}$} & 4.24 & 3.93 & 4.27 & 4.29 \\
\hline & Strongly agree & Agree & Strongly agree & Strongly agree \\
\hline \multirow{2}{*}{$\begin{array}{l}\text { Participation in ISFP activities } \\
\text { in the field }\end{array}$} & 4.02 & 4.00 & 3.93 & 4.17 \\
\hline & Agree & Agree & Agree & Agree \\
\hline \multicolumn{5}{|c|}{ Access to Livelihood Opportunities } \\
\hline \multirow{2}{*}{$\begin{array}{l}\text { Involvement in ISFP-related } \\
\text { livelihoods }\end{array}$} & 3.95 & 3.88 & 4.24 & 4.24 \\
\hline & Agree & Agree & Strongly agree & Strongly agree \\
\hline \multicolumn{5}{|l|}{ Access to PO services } \\
\hline \multirow{2}{*}{$\begin{array}{l}\text { Access to the equipment of the } \\
\text { PO }\end{array}$} & 3.85 & 4.12 & 4.15 & 4.07 \\
\hline & Agree & Agree & Agree & Agree \\
\hline \multicolumn{5}{|c|}{ Access to major forest-based resources } \\
\hline \multirow{2}{*}{ Land } & 4.17 & 3.98 & 3.93 & 4.12 \\
\hline & Agree & Agree & Agree & Agree \\
\hline \multirow{2}{*}{ Timber } & 4.10 & 4.00 & 4.00 & 3.88 \\
\hline & Agree & Agree & Agree & Agree \\
\hline \multirow{2}{*}{ NTFPs } & 3.88 & 3.76 & 3.88 & 3.85 \\
\hline & Agree & Agree & Agree & Agree \\
\hline \multirow{2}{*}{ Water } & 3.80 & 3.95 & 4.05 & 4.10 \\
\hline & Agree & Agree & Agree & Agree \\
\hline \multicolumn{5}{|l|}{ Sharing of Responsibilities } \\
\hline \multirow{2}{*}{ Costs and responsibilities } & 4.15 & 4.15 & 3.98 & 4.17 \\
\hline & Agree & Agree & Agree & Agree \\
\hline
\end{tabular}

Scale Interpretation

$1.00-1.80$ strongly disagree

1.81-2.60 disagree

2.61-3.40 neutral

3.41-4.20 agree

4.21-5.00 strongly agree 


\subsubsection{PO Policies and Overall View of ISFP Implementation}

Respondents agreed that government policies on the ISFP project, particularly tenurial agreement, reforestation, livelihood development, to name a few were generally fair and just (Table 8). Likewise, they agreed that ISFP policies conform well to those of the national policies on forest management. Overall, the implementation of ISFP was strongly agreed to be fair and just. The respondents saw it as the main contributor for the improvement of their well-being and the condition of the environment.

Table 8. Perception and overall view of ISFP policies and implementation.

\begin{tabular}{lcc}
\hline & Mean & Perception \\
\hline ISFP Policies at present are fair and just & 4.07 & Agree \\
\hline Policies conforms with national policies on forest management & 4.02 & Agree \\
\hline Implementation of ISFP is fair and just & 4.22 & Strongly agree \\
\hline Scale Interpretation & & \\
1.00-1.80 strongly disagree & & \\
1.81-2.60 disagree & & \\
2.61-3.40 neutral & & \\
3.41-4.20 agree & & \\
4.21-5.00 strongly agree & &
\end{tabular}

\subsubsection{Factors Associated with Perceived Equity}

The relationships on the factors associated with perceived equity were analyzed to distinguish a significant relationship and not the cause and effect.

a. Perception of Equity in Terms of Gender and Sex, Education and Educational Attainment, and

Membership and Number of Years as a PAFISFA

The results of Point-biserial correlation and Spearman's correlation tests indicated that perceived equity in gender and sex, education and educational attainment, and membership and number of years as a PAFISFA were not significantly related to each other (Table 9).

b. Perception of Equity in Terms of Economic Status and Annual Income

The economic status of the respondents was significantly related to the perception of equity on leadership, participation in community forestry activities, involvement in community forestryrelated livelihoods, and access to equipment. Meanwhile, a significant correlation was also observed with the level of participation in PO meetings and the sharing of cost and responsibilities.

The well-off were involved in the process and implementation of ISFP; however, these negative correlations, which implied increasing economic status and decreasing perception on equity and vice versa, suggest that the equipment owned by the PO was not fairly accessible to those who are well-off. The well-off were also not fairly represented as a member of the executive council/leader. Likewise, the well-off were not fairly participating in community forestry activities and $\mathrm{PO} /$ community meetings. It was also the well-off who were not fairly involved in community forestry-related livelihood and sharing on cost and responsibilities. These results may be an implication that there were still conflicts within the community.

Table 9. Summary of the results of Point-biserial correlation test and Spearman's correlation test between the four perceptions of equity and eleven impact categories

\begin{tabular}{|c|c|c|c|c|c|c|c|c|}
\hline \multirow{3}{*}{ Impact Category } & \multicolumn{8}{|c|}{ Perception of Equity } \\
\hline & \multicolumn{2}{|c|}{$\begin{array}{c}\text { Gender and } \\
\text { Sex }\end{array}$} & \multicolumn{2}{|c|}{$\begin{array}{c}\text { Education and } \\
\text { Educational } \\
\text { Attainment }\end{array}$} & \multicolumn{2}{|c|}{$\begin{array}{l}\text { Economic } \\
\text { Status and } \\
\text { Income }\end{array}$} & \multicolumn{2}{|c|}{$\begin{array}{c}\text { Membership and } \\
\text { Number of Years } \\
\text { in PAFISFA }\end{array}$} \\
\hline & Coef. & Sig. & Coef. & Sig. & Coef. & Sig. & Coef. & Sig. \\
\hline Leadership & & & & & - & $* *$ & & \\
\hline $\begin{array}{l}\text { Participation in } \\
\text { PO/community } \\
\text { meetings }\end{array}$ & & & & & - & $*$ & & \\
\hline
\end{tabular}




\begin{tabular}{|c|c|c|c|c|c|c|c|c|}
\hline \multirow{3}{*}{ Impact Category } & \multicolumn{8}{|c|}{ Perception of Equity } \\
\hline & \multicolumn{2}{|c|}{$\begin{array}{l}\text { Gender and } \\
\text { Sex }\end{array}$} & \multicolumn{2}{|c|}{$\begin{array}{c}\text { Education and } \\
\text { Educational } \\
\text { Attainment }\end{array}$} & \multicolumn{2}{|c|}{$\begin{array}{l}\text { Economic } \\
\text { Status and } \\
\text { Income }\end{array}$} & \multicolumn{2}{|c|}{$\begin{array}{c}\text { Membership and } \\
\text { Number of Years } \\
\text { in PAFISFA }\end{array}$} \\
\hline & Coef. & Sig. & Coef. & Sig. & Coef. & Sig. & Coef. & Sig. \\
\hline $\begin{array}{l}\text { Participation in } \\
\text { community forestry } \\
\text { activities }\end{array}$ & & & & & - & $* *$ & & \\
\hline $\begin{array}{l}\text { Involvement in } \\
\text { community forestry- } \\
\text { related livelihoods }\end{array}$ & & & & & - & $* *$ & & \\
\hline Access to Equipment & & & & & - & $* *$ & & \\
\hline $\begin{array}{l}\text { Sharing of costs } \\
\text { responsibilities }\end{array}$ & & & & & - & $*$ & & \\
\hline
\end{tabular}

\subsubsection{Relationship Between ISFP Goals and Equity}

The two goals of ISFP, living condition and forest condition, were categorized as impact categories in understanding equity. Their relationship with equity was assessed using the perception of equity in terms of leadership roles and local participation, and access to major forest-based resources.

a. On Leadership Roles and Local Participation

The perception of equity in terms of leadership roles and local participation was significantly related to water (

Table 10).

The study implies that the fair representation on leadership roles and local participation resulted in water clarity or cleanliness on water resources. It was an indicator of improving forest conditions (FAO, 2013). There was an increase in water quality due to the persistent efforts of local leaders to implement policies and activities that maintain cleanliness in the community.

b. On Access to Major Forest-based Resources

The perception of equity in terms of access to major forest-based resources was significantly related to the sufficiency of income and land (

Table 10).

This suggests that fair distribution and enjoyment on access to major forest-based resources had significantly contributed to income sufficiency and proper land management.

Table 10. Summary of the results of Spearman's correlation test between the two perception of equity and 25 impact categories

\begin{tabular}{|c|c|c|c|c|}
\hline \multirow{3}{*}{$\begin{array}{l}\text { Impact category - } \\
\text { Goals of ISFP }\end{array}$} & \multicolumn{4}{|c|}{ Perception of Equity } \\
\hline & \multicolumn{2}{|c|}{$\begin{array}{l}\text { Leadership roles and local } \\
\text { participation }\end{array}$} & \multicolumn{2}{|c|}{$\begin{array}{c}\text { Access to major forest-based } \\
\text { resources }\end{array}$} \\
\hline & Coef. & Sig. & Coef. & Sig. \\
\hline \multicolumn{5}{|l|}{ Living condition } \\
\hline $\begin{array}{l}\text { Sufficiency of } \\
\text { income }\end{array}$ & & & + & $*$ \\
\hline Land & & & + & $*$ \\
\hline \multicolumn{5}{|l|}{ Forest condition } \\
\hline Water clarity & + & $*$ & & \\
\hline
\end{tabular}


* Significance at the $5 \%$ level

**Significance at the $1 \%$ level

\subsection{Issues and Challenges with ISFP}

Many livelihood opportunities were provided in the community through ISFP. As the majority worked as farmers, the individual annual income was equated to low yearly income. According to the income class devised by the Family Income and Expenditure Survey (FIES) of the Philippine Statistics Authority (2012), the respondents who were in the lowest income range were considered poor. Even though the income from forest-based livelihood was perceived to be sufficient and increasing, for some of the respondents, the changes in the market (selling and trading) of forest products made their income insufficient. Few of the respondents started to engage in non-forestbased livelihood as they have indicated that forest-based livelihoods were inadequate to provide income. Similar in the case of the Barrobob community (Pulhin et. al, 2008), the practice of selling land rights existed in order to cope with daily needs. This, therefore, posed an emerging problem in these communities.

The devolution of ISFP was not sustainable because of the limited technical and financial capacity of the local government (Enrique, 1992; Orias and Bande, 2018). Insufficiency in budget and manpower also hindered the regular meetings between the Barangay and the organization, which could have been instrumental in developing collaborations on livelihood development programs. The organization meetings with the Barangay happened on a quarterly basis. With the continuous development in the barangay, non-related ISFP organizations were established in the community (Colina, 2014) and the membership within different organizations were overlapping, which leads to an increasing number of inactive members in PAFISFA. Few of the respondents joined the newly established organizations in the hopes of earning additional income.

The overlapping land use in Barangay Patag added a conflict around community development trajectories. Parts of the ISFP lands are adjacent or overlapping with Northern Negros Natural Park, a protected area. By law, upland farming is regulated in protected areas, and limited land occupancy is exclusive only for tenured migrants. Other extractive activities such as hunting and timber cutting are strictly prohibited. Hence, forest areas that are excluded from ISFP were then declared as areas located within a national park, critical watershed, proclaimed watershed, or other reservation. This has displaced forest-dependent livelihoods of some households.

\section{Conclusions}

The case of the ISF Program in Silay City stated that the ISFP had positive impacts on livelihoods, income, forest condition, and equity. Livelihoods were heavily dependent on forest resources as upland farming was adopted by program participants. ISFP helped increased forest-based livelihoods and ownership of assets in the community. Income was perceived to be increasing and sufficient; however, in general, ISFP had a low impact because program participants were still poor. Forest conditions also greatly improved because of the collective efforts in the community and ISFP had a high impact on the current condition of the forest. Meanwhile, equity was fairly shared through ISFP in terms of gender, education, economic status, and membership; hence, equity was not a concern in the community. The study also identified the factors associated with equity and the relationships between equity and ISFP goals were assessed. Likewise, the challenges in sustaining the program were identified and there is a need to pursue some strategies to maintain and continuously improve the positive impacts on the socio-ecological conditions of the community. This may include: 1 ) developing alternative livelihoods to improve local income of the respondents; 2) providing capacity building and organizational trainings to improve leadership and local participation among PO members; and 3) conduct a participatory land use planning to harmonize rights, livelihoods and development plans among local stakeholders towards ensuring ecological integrity and well-being of the local community (Chechina et al., 2018).

Author Contributions: NAN contributed to the data collection, data analysis, and wrote the manuscript. DTG contributed to the study design, supervised the study, and reviewed the final manuscript. 
Conflicts of Interest: The authors declare no conflict of interest.

Acknowledgments: The authors would like to acknowledge support from the Nacionales, Amoroso, and Badian Family and would like to thank the staffs in PENRO Negros Occidental, Office of the Mayor Silay City, Barangay Patag Office, and PAFISFA.

\section{References}

Adams, W. M., Aveling, R., Brockington, D., Dickson, B., Elliott, J., Hutton, J., ... \& Wolmer, W. (2004). Biodiversity Conservation and The Eradication of Poverty. Science, 306(5699), 1146-1149. https://doi.org/10.1126/science.1097920

Amanor, K. S. (2005). Equity in forest benefit sharing and poverty alleviation. In Equity in Forest Benefit Sharing: Stakeholders' Views. Tropenbos International-Ghana, Workshop proceedings (Vol. 3, pp. 15-23). Retrieved from https://www.tropenbos.org/file.php/217/benefitsharingsmall.pdf.

Antinori, C., \& Rausser, G. C. (2008). Ownership and control in Mexico's community forestry sector. Economic Development and Cultural Change, 57(1), 101-136. https://doi.org/10.1086/590459

CENRO, Cadiz City. (2016). Northern Negros Natural Park. Brgy. Patag, Silay City. Biodiversity Monitoring System, June 2016. Bantayan Park, Bago City, Negros Occidental.

Chechina, M., Neveux, Y., Parkins, J. R., \& Hamann, A. (2018). Balancing conservation and livelihoods: A study of forest-dependent communities in the Philippines. Conservation and Society, 16(4), 420-430. http://dx.doi.org/10.4103/cs.cs_16_182

City Planning and Development Office - City Government of Silay. (2016). Barangay Patag Profile.

Colina, A., IV. (2014). Organic farming for peace, dev't. SunStar Philippines. Retrieved from https://www.sunstar.com.ph/article/376682/Organic-farming-for-peace-devt

DENR. 2016. NNNP Basic Features and Profile.

Dizon, J. T. (2004). Co-management of the commons: some experiences with community-based resource management in the Philippine uplands. In Commons in an Age of Global Transition: Challenges, Risks and Opportunities, 10th IASCP Conference, Oaxaca, Mexico.

Enrique, R. (1992). Integrated social forestry program [ISFP] of Cenro 3-10, Guiguinto, Bulacan [Philippines]. University of the Philippines at Los Baños.

FMB-DENR. (2021). Historical Background. Retrieved from https://forestry.denr.gov.ph/index.php/about-fmb/historical-background

Food and Agriculture Organization of the United Nations. (2013). Forests and Water. International Momentum and Action.

Gevaña, D. (2009). Equity and tenure regime in Community-based Forest Management in Nueva Vizcaya, Philippines (Master's thesis). University of the Philippines Los Baños, Laguna, Philippines.

Hansen, M. C., Potapov, P. V., Moore, R., Hancher, M., Turubanova, S. A., Tyukavina, A., ... \& Townshend, J. (2013). High-resolution global maps of 21st-century forest cover change. Science, 342(6160), 850-853. https://doi.org/10.1126/science.1244693

Levang P., E. Dounias, and S. Sitorus. (2005). Out of the forest, out of poverty? Forests, Trees and Livelihoods, 15(2), 211-235. https://doi.org/10.1080/14728028.2005.9752521

Maohong, B. (2012). Deforestation in the Philippines, 1946-1995. Philippine Studies: Historical \& Ethnographic Viewpoints, 60(1), 117-130. https://doi.org/10.1353/phs.2012.0011

Macahilo, M. (2018). Organic Agriculture: A Boon to Patag Farmers. Agriculture Monthly. Retrieved from https://www.agriculture.com.ph/2018/07/12/organic-agriculture-a-boon-to-patagfarmers/

Masipiquena, A. (1993). People-centered approach to forest resource management: the case of integrated social forestry program implementation in selected project sites in Isabela, Philippines. University of the Philippines at Los Baños.

Orias, A. B., \& Bande, M. M. (2018). Policy and Socio-ecological Assessment of the Integrated Social Forestry Program after 25 Years of Implementation in St. Bernard, Southern Leyte, 
Philippines. International Journal of Environmental and Rural Development, 9(1), 7-13. https://doi.org/10.32115/ijerd.9.1_7

Pasa, Arturo E. (2007). Rewarding smallholders for their environmental services: Lessons learned from Midwestern Leyte. Improving the Triple Bottom Line Returns from Small-scale Forestry, Ormoc, the Philippines, 18 - 21 June 2007. Gatton, Qld, Australia: The University of Queensland. Retrieved from https://espace.library.uq.edu.au/view/UQ:108378

Peras R.J.J., Pulhin J.M., Gevaña D.T., Inoue M. (2021) Natural Resource Base as a Foundation of Human Security. In Pulhin J.M., Inoue M., Shaw R. (eds) Climate Change, Disaster Risks, and Human Security. Disaster Risk Reduction (Methods, Approaches and Practices) (pp 113-136). Springer. https://doi.org/10.1007/978-981-15-8852-5_6

Philippine Statistics Authority. (2016). 2013 Annual Survey of Philippine Business and Industry Agriculture, Forestry and Fishing for Establishments with Total Employment of 20 and Over: Preliminary Results. Retrieved from https://psa.gov.ph/content/2013-annual-surveyphilippine-business-and-industry-agriculture-forestry-and-fishing

Pulhin, J. M. (2002). Trends in Forest Policy of the Philippines. Policy Trend Report. College of Forestry and Natural Resources. University of the Philippine, Los Baños. pp 29-41. Retrieved from https://aboutphilippines.org/files/Trends-in-Forest-Policy-Philippines.pdf

Pulhin, J. M., Dizon, J. T., Cruz, R. V. O., Gevana, D. T., \& Dahal, G. (2008). Tenure Reform on Philippine Forest Lands: Assessment ff Socio-Economic and Environmental Impacts. CIFOR

Pulhin, J., Gevana, D., Pulhin, F. (2017). Community-Based Mangrove Management in the Philippines: Experience and Challenges in the Context of Changing Climate. In DasGupta, R \& Shaw, R. (eds.) Participatory Mangrove Management in a Changing Climate (pp 247-262). Springer.

Ramirez, D. (1991). Some Social Insights on Philippine Programs in the Forestry Sector. Transactions of the National Academy of Science and Technology. Republic of the Philippines. Volume XIII.

Richards, M., Maharjan, M., \& Kanel, K. (2003). Economics, poverty and transparency: measuring equity in forest user groups. Journal of Forest and Livelihood, 3(1), 91-106.

Ruzol, C. D., Camacho, A. C. D., Sabino, L. L., Garcia, J. E., Gevaña, D. T., \& Camacho, L. D. (2020). A materialist-idealist divide? Policy and practice in participatory mangrove rehabilitation in the Philippines. Environmental Science \& Policy, 112, 394-404. https://doi.org/10.1016/j.envsci.2020.06.026

UN Habitat. (2020). Module 8. Monitoring and Reporting the SDGs. Secure Tenure Rights to Land.

Yamane, T. (1967). Statistics, An Introductory Analysis ( $2^{\text {nd }} E d$.). Harper and Row.

Yamane, T. (1999). Statistics: An introductory Analysis, (3 $3^{\text {rd }}$ Ed.). Harper and Row. 